\title{
Measuring Quality of E-Learning and Desaire2Learn in the College of Science and Humanities at Alghat, Majmaah University
}

\author{
Abdelmoneim Ali Mohamed \\ Department of Mathematics, College of Science and \\ Humanities at Alghat, Majmaah University, \\ Majmaah 11952, Saudi Arabia.
}

\author{
Faisal Mohammed Nafie \\ Department of Computer Science, College of Science and \\ Humanities at Alghat, Majmaah University, \\ Majmaah 11952, Saudi Arabia.
}

\begin{abstract}
E-learning and Desaire2Learn (D2L) system were used in several higher education institutions; the learning satisfaction depends on the quality of the system applied to serve this issue and its importance in users mind. Therefore, this study, intended to explore the degree of students and Satisfaction of faculty members with the importance and quality of e-learning used and D2L system as a tool for learning some courses. We took a sample of 57 faculty members and 135 students participated in this study. We used two questionnaires as a tool to collect data from participants, one for faculty members and the other for students; both of these questionnaires had the same idea with different questions. We implemented Statistical Package for Social Science (SPSS) to analyze data. The results show that the Satisfaction of faculty members is high with the quality of elearning and D2L system as a method of teaching, moderate satisfaction with using D2L tools, the result shows there was a positive relationship between e-learning quality and using D2L tools in teaching. But the result record high satisfaction from students towards the quality of e-learning; the D2L system as a method of learning and the result shows there was no statistically significant effect of gender on the D2L system quality. Finally, the study discussed the implications and recommendations of the work.
\end{abstract}

Keywords-E-learning; Desire2Learn; D2L quality; E-learning quality; learning satisfaction

\section{INTRODUCTION}

E-learning is an interactive distance learning system that provides the learner according to demand and relies on an integrated digital electronic environment, aimed at building and delivering courses through electronic networks, counseling, guidance, organizing tests, managing and evaluating sources and processes [1].

Technological development has encouraged the interest of distance education and e-learning to take advantage of its features, where students can attend lectures through smart devices, and this saves time and effort for educational institutions as well as students [2], in addition, to improve the educational product and enhancing quality of the learner [3].

There are many systems used in e-learning and distance education, including the D2L system, which requires training to the use of its tools. In this system, there were obstacles, namely the lack of skilled trainers, the weakness of the Internet services, the inability of faculty members to use some tools such as online room, and the inability of students to use some tools, all of which require continuous training, flexibility, technical support, and system quality denotes two sides of the information system itself, such as processing speed, ease of use, necessary requirements, and navigability. These are important factors that are the responsibility of the technical group, from the inception of the system to its planning and implementation [4].

The purpose of this study was to determine the level of satisfaction of students and faculty members with distance learning by teaching some online courses using e-learning system D2L, which was used to support traditional teaching method, ready to be widely disseminated, especially on theoretical courses that do not require labs.

\section{LECTURE REVIEW}

\section{A. Introduction to E-Learning}

E-learning is defined as "an educational system that uses information technology and computer networks to support and expand the scope of the learning process through a range of media, including computers, the Internet and electronic programs" [5].

E-learning is appealing for many reasons. For most, online courses do not require regular attendance at scheduled lectures. Thus, those working full time or who have other responsibilities are drawn to online courses, as is the case with many nontraditional students. Another convenience of online education is the ability for students to learn materials at their own pace [6].

\section{B. Distance Education}

Distance education has become a component of the educational system in most universities; the usual trend in distance education has been that new technologies have been applied to make the independent study more closely resemble the traditional classroom [7]. This occurred by great development in the field of telecommunications and Internet services. The term 'distance education' utilized to define instructional delivery that does not restrict students 
to being physically present in the same location as an instructor [8].

\section{Systems used}

Several systems used to serve this purpose. One of these systems is the Desire2Lean system as a new e-learning platform (Horn, Anne, and Sue Owen, 2011), which is an online education management system designed to help faculty members and students interact in online lectures, use online coursework, as well as activities complementary to regular classroom teaching. Staff members were able to provide course materials, dialogue forums, discussion, short online exams, as well as academic and other resources.

The importance of Desire2Learn lies in providing the Library with the opportunity to deliver its service and support, online, as it does in the library's physical spaces [9].

Majmaah University used the D2L system in the educational processes and allocated some courses for distance teaching, this step found great satisfaction from students and staff members.

\section{Objectives}

The main objectives of this study were to explore the degree of students and faculty members Satisfaction with the importance and quality of e-learning and Desaire2Learn system used as a tool for learning some courses.

\section{Methodology}

In this study test staff members and students level of satisfaction towards distance learning and e-learning system (Desaire2Learn) used in the College of Science and Humanities at Alghat in Majmaah University. Two questionnaires were used as the main instrument to collect data from both to determine their satisfaction towards the importance, quality of distance learning and quality of elearning, which used (D2L) system. The sample taken from faculty members teaching in the College of Science and Humanities at Alghat and students enrolled in the first semester in 2017.The sample of 57 faculty members and 135 students responded to the questionnaire. The faculty members respondents were 31 male $(54.4 \%)$ and 26 female $(45.6 \%)$. The student respondents were 76 male $(56.7 \%)$ and 59 female $(43.3 \%)$.

The reliability test conducted by a pilot test of the instrument and Cronbach's Alphas for 30 staff members and 20 students instrument items were 0.89 and 0.93 respectively, which indicates the good internal consistency of the items.

\section{RESUlTS}

Descriptive statistics were utilized to measure respondents (students \& faculty members) scores among the importance of distance learning, quality of e-learning and quality of the Desiare2Learn system.

Firstly: faculty member's satisfaction towards Importance of e-learning based on seven items.

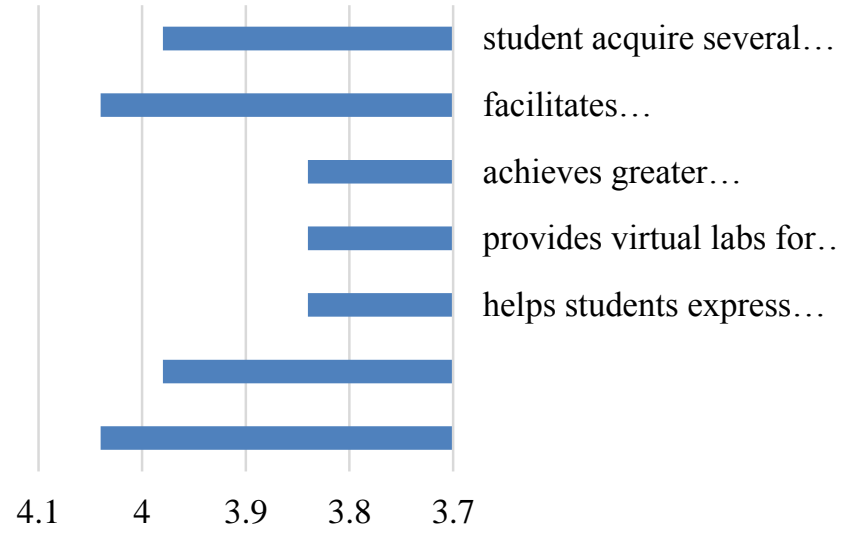

Fig. 1. Descriptive statistics for faculty members Importance in distance learning.

E-learning is a good method of teaching and using modern mechanisms $(\mathrm{M}=4.04, \mathrm{SD}=0.755)$, increased of electronic communication changed the method of training $(\mathrm{M}=3.98, \quad \mathrm{SD}=0.694)$, "DL" helps students express themselves in different ways, and gives them easy access to their teachers $(\mathrm{M}=3.84, \mathrm{SD}=0.922)$ which is earned the lower score of participants, DL provides virtual labs for scientific experiments $(\mathrm{M}=3.84, \mathrm{SD}=0.649)$, $\mathrm{DL}$ facilitates communication between learner and learning resources $(\mathrm{M}=3.84, \quad \mathrm{SD}=0.797), \quad \mathrm{DL}$ facilitates communication between learner and learning resources $(\mathrm{M}=4.04, \mathrm{SD}=0.462)$ received the highest score for the importance of DL, with DL, the student can acquire several skills (M=3.98, $\mathrm{SD}=0.719$ ) (see Fig. 1). In all these items, the satisfaction degree on the "Importance in distance learning" is high.

E-learning quality composed of nine items grouped into three variables (see Table I).

The results show that respondent was highly satisfied with "internet services" $(\mathrm{M}=4.20, \mathrm{SD}=0.57)$, and high satisfaction with both "Improving the educational environment" $(M=3.96, S D=0.44)$ \& "Training" $(M=3.83$, $\mathrm{SD}=0.43$ ) and respondent were highly satisfied with elearning quality where the overall score is $(M=3.91$, $\mathrm{SD}=0.34$ ).

TABLE I. QUALITY OF E-LEARNING (SATISFACTION OF FACULTY MEMBERS

\begin{tabular}{|c|c|c|c|}
\hline Variable & M & SD & Satisfaction \\
\hline internet services & 4.20 & 0.57 & high \\
\hline $\begin{array}{c}\text { Improving the } \\
\text { educational } \\
\text { environment }\end{array}$ & 3.96 & 0.44 & high \\
\hline Training & 3.83 & 0.43 & high \\
\hline Quality of e-learning & 3.91 & 0.34 & high \\
\hline
\end{tabular}

Indicator: 1-1.8 very low, 1.81-2.6 low, 2.61-3.4 moderate, 3.41- 4.2 high, 4.21-5 very high 
TABLE II. D2L QUALITY (SATISFACTION OF FACUlTy MEMBERS)

\begin{tabular}{|l|l|l|l|}
\hline Variable & M & SD & Satisfaction \\
\hline flexibility & 3.75 & 0.81 & high \\
\hline Manuals & 4.02 & 0.77 & high \\
\hline Technical support & 3.61 & 0.90 & high \\
\hline $\begin{array}{l}\text { Providing training } \\
\text { courses }\end{array}$ & 3.96 & 0.46 & high \\
\hline D2L Quality & 3.84 & 0.55 & high \\
\hline
\end{tabular}

D2L quality composed of four items (see Table II). The results show that respondent was highly satisfied with the quality of the D2L system in all its variables.

Table III displays the mean and standard deviation scores of faculty member's usage of D2L tools in teaching. The results show that respondent was moderately satisfied with their using D2L tools in teaching their courses where the overall score is $(\mathrm{M}=2.92, \mathrm{SD}=0.51)$ by determining each variable of D2L.

The result appeared high satisfied with, "Upload course content and lessons" $(\mathrm{M}=3.96, \mathrm{SD}=0.46)$ and "Use the Dropbox tool" $(\mathrm{M}=4.09, \mathrm{SD}=1.17)$, moderate satisfied with "Use the discussion tool" $(\mathrm{M}=2.79, \mathrm{SD}=0.78)$ and low satisfied with "Use The Group and discussion tool" $(\mathrm{M}=2.53, \mathrm{SD}=0.78)$, "Use the Quiz tool" $(\mathrm{M}=2.56, \mathrm{SD}=0.95)$, Using Online Room tool" (M=1.91,SD=0.662) and "Giving lectures remotely" $(\mathrm{M}=2.92, \mathrm{SD}=1.24)$.

Table IV shows examining the relation between the faculty members using D2L tools in teaching students vs Elearning quality and System quality (D2L). The result show there was a positive relationship e-learning quality and using D2L tools in teaching " $(\mathrm{r}=0.45, \mathrm{P}=0.000)$, positive relationship system quality (D2L) and using D2L tools in teaching $(\mathrm{r}=0.40, \mathrm{P}=0.002)$ ".

TABLE III. USING D2L ToOls (SATISFACTION OF FACUlTy MEMBERS)

\begin{tabular}{|l|l|l|l|}
\hline Variable & M & SD & Satisfaction \\
\hline $\begin{array}{l}\text { Upload course content } \\
\text { and lessons }\end{array}$ & 3.96 & 0.46 & high \\
\hline Use the discussion tool & 2.79 & 0.79 & moderate \\
\hline $\begin{array}{l}\text { Use The Group and } \\
\text { discussion tool }\end{array}$ & 2.53 & 0.78 & low \\
\hline Use the Dropbox tool & 4.09 & 1.17 & high \\
\hline Use the Quiz tool & 2.56 & 0.95 & low \\
\hline $\begin{array}{l}\text { Using Online Room } \\
\text { tool }\end{array}$ & 1.91 & 0.662 & low \\
\hline $\begin{array}{l}\text { Giving lectures } \\
\text { remotely }\end{array}$ & 2.58 & 1.24 & low \\
\hline Uses of D2L tools & 2.92 & 0.51 & moderate \\
\hline
\end{tabular}

Indicator: 1-1.8 very low, 1.81-2.6 low, 2.61-3.4 moderate, 3.41- 4.2 high, 4.21-5 very high
TABLE IV. THE EFFECT OF E-LEARNING QUALITY AND SYSTEM QUALITY (D2L) TOWARDS USING TOOLS (SATISFACTION OF FACULTY MEMBERS) $(\mathrm{N}=57)$

\begin{tabular}{|l|l|l|}
\hline \multicolumn{2}{|c|}{ Using satisfaction } \\
\hline & r & p \\
\hline E-learning Quality & 0.45 & 0.000 \\
\hline System Quality (D2L) & 0.40 & 0.002 \\
\hline
\end{tabular}

Note. Magnitude: $.01 \geq r \geq .09=$ Negligible, $.10 \geq r \geq .29=$ Low, $.30 \geq r \geq .49=$ Moderate, $.50 \geq r \geq .69$ $=$ Substantial, $\mathrm{r} \geq .70=$ Very Strong. ${ }^{*} \mathrm{p}<.05$.

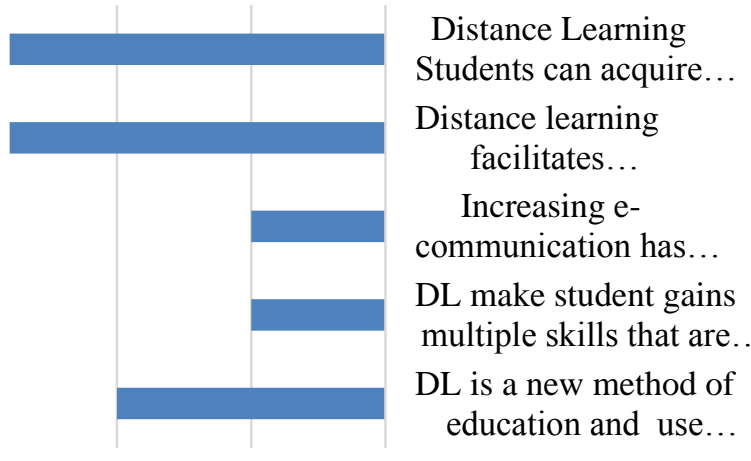

$\begin{array}{llll}4 & 3.95 & 3.9 & 3.85\end{array}$

Fig. 2. The importance of distance education in the students' perspective.

Secondly: Students' satisfaction towards the importance of distance education in the students' perspective composed of five items (see Fig. 2). All items were of similar average, which indicates to students' awareness of the importance of distance education and e-learning. The degree of satisfaction is high in all items.

E-learning quality composed of ten items grouped into three variables (see Table V).

The results show that respondent was highly satisfied with "internet services" $(\mathrm{M}=3.69, \mathrm{SD}=0.64)$, and high satisfaction with both "Improving the educational environment" (M=3.87, $\mathrm{SD}=0.53)$ \& "Training" $(\mathrm{M}=3.84$, $\mathrm{SD}=0.59)$ and respondent were highly satisfied with elearning quality where the overall score is $(M=3.80$, $\mathrm{SD}=0.51)$.

D2L quality composed of seven items grouped into for variables (see Table VI). The results show that respondent was highly satisfied with the quality of the D2L system in all its variables.

TABLE V. The QuALity of E-LEARNing (STUdENTS' SATISFACTION)

\begin{tabular}{|l|l|l|l|}
\hline Variable & $\mathbf{M}$ & SD & Satisfaction \\
\hline internet services & 3.69 & 0.64 & high \\
\hline $\begin{array}{l}\text { Improving the educational } \\
\text { environment }\end{array}$ & 3.87 & 0.53 & high \\
\hline Training & 3.84 & 0.59 & high \\
\hline Quality of e-learning & 3.80 & 0.51 & high \\
\hline
\end{tabular}

Indicator: 1-1.8 very low, 1.81-2.6 low, 2.61-3.4 moderate, 3.41- 4.2 high, 4.21-5 very high 
TABLE VI. D2L QUALITY (STUDENT'S SATISFACTION)

\begin{tabular}{|l|l|l|l|}
\hline Variable & M & SD & Satisfaction \\
\hline flexibility & 3.70 & 0.69 & high \\
\hline Manuals & 3.88 & 0.67 & high \\
\hline Technical support & 3.76 & 0.82 & high \\
\hline Providing training courses & 3.91 & 0.67 & high \\
\hline D2L Quality & 3.81 & 0.54 & high \\
\hline
\end{tabular}

TABLE VII. THE EFFECT OF SYSTEM QUALITY (D2L) TOWARDS USING TOOLS (STUDENT'S SATISFACTION) $(\mathrm{N}=135)$

\begin{tabular}{|l|l|l|}
\hline \multicolumn{3}{|c|}{ Quality of e-learning student satisfaction } \\
\hline & r & p \\
\hline System Quality (D2L) & 0.823 & 0.000 \\
\hline
\end{tabular}

Table VII shows "there was a high positive correlation between System Quality (D2L) and quality of e-learning student satisfaction, $r=0.823, \mathrm{n}=135, \mathrm{p}=0.000$ ".

The main effect of gender is the "system quality D2L student satisfaction, (male and female)". Was found for satisfaction with "Quality of e-learning students satisfaction" was not significant, $\mathrm{F}(1,132)=1.993, \mathrm{P}<0.16$.

\section{CONCLUSION}

This study tested the satisfaction of both faculty members and students on the e-learning and Desire2Learn quality. The results reached the following conclusions: First, the results showed the satisfaction of faculty members with the quality of e-learning and its components, which include namely internet services, Improving the educational environment and manuals provided by the Deanship of elearning at the university, as high satisfies. At the same time, the study shows student satisfaction on the quality of e-learning which includes the same variables "internet services, Improving the educational environment and manuals", as high satisfies.

The quality of D2L registered high satisfaction in all its variables, namely, flexibility, manuals, technical support and providing training courses for both staff members and student participants. This confirms what was mentioned in the previous study, which concluded that students preferred
Desire2Learn as their technology choice for their online classes [10].

The study showed that the satisfaction of staff members with the use of D2L tools was moderate in general, week specifically in "Quiz tool", "Online Room", "Group and discussion tool", and "Giving lectures remotely" which in the line with of [11] which show that Desire2Learn faculty significantly increased their level of use for all but two of the tools that didn't see a statistically significant increase in faculty usage were the SCORM and "Synchronous Session which corresponded to", "Online Room", "Group and discussion tool".

\section{REFERENCES}

[1] Simonson, M., Smaldino, S., \& Zvacek, S. M. (Eds.). (2014). Teaching and learning at a distance: Foundations of distance education. IAP.

[2] Clark, R. C., \& Mayer, R. E. (2016). E-learning and the science of instruction: Proven guidelines for consumers and designers of multimedia learning. John Wiley \& Sons.

[3] Amasha, M. A., \& Alkhalaf, S. (2015). A Model of an E-Learning Web Site for Teaching and Evaluating Online. ArXiv preprint arXiv: 1501.05578 .

[4] Machado-Da-Silva, F. N., Meirelles, F. D. S., Filenga, D., \& Brugnolo Filho, M. (2014). STUDENT SATISFACTION PROCESS IN VIRTUAL LEARNING SYSTEM: Considerations Based on Information and Service Quality from Brazil's Experience. Turkish Online Journal of Distance Education, 15(3).

[5] Kumar, S. (2014). Ubiquitous smart home system using android application. arXiv preprint arXiv:1402.2114.

[6] Block, A., Udermann, B., Felix, M., Reineke, D., \& Murray, S. R. (2006). Achievement and satisfaction in an online versus a traditional health and wellness course (Doctoral dissertation. University of Wisconsin--La Crosse).

[7] Moore, M. G. (Ed.). (2013). Handbook of distance education. Routledge.

[8] Riggins, M. E. (2014). Online versus face-to-face biology: A comparison of student transactional distance, approach to learning, and knowledge outcomes. The University of Southern Mississippi.

[9] Horn, A., \& Owen, S. (2011, January). Deakin University Library: an active partner in the implementation of the new generation e-learning platform Desire2Learn. In IATUL 2011: Libraries for an open environment, strategies, technologies, and partnership: Proceedings of the 32nd International Association of Scientific and Technological University Libraries Conference (pp. 1-11). IATUL.

[10] Chawdhry, A., Karen Paullet, and Daniel Benjamin. "Comparatively assessing the use of Blackboard versus D2L: student perceptions of the online tools." Issues in Information Systems 12.2 (2011): 273280.

[11] Rucker, R., \& Downey, S. (2016). Faculty technology usage resulting from institutional migration to a new learning management system. Online Journal of Distance Learning Administration, 19(1), n1. 